\title{
RESEARCH Note \\ New depth record of the dappled flounder Paralichthys woolmani (Pleuronectiformes: Paralichthyidae) in the Gulf of California, México
}

\author{
Nuevo registro de profundidad del lenguado moteado Paralichthys woolmani \\ (Pleuronectiformes: Paralichthyidae) en el Golfo de California, México

\section{Eloísa Herrera-Valdivia ${ }^{1}$, Juana López-Martínez ${ }^{*}$ and Rufino Morales-Azpeitia ${ }^{1}$}

\begin{abstract}
${ }^{1}$ Centro de Investigaciones Biológicas del Noroeste S. C., Unidad Sonora Campus Guaymas, Km 2.35 Carretera a las Tinajas S/N Colonia Tinajas, Guaymas, Sonora, México. C.P. 85460.*jlopez04@cibnor.mx

Abstract.- Ten specimens of the dappled flounder Paralichthys woolmani were captured at a depths from 109 to $248.1 \mathrm{~m}$ in the central Gulf of California in an exploration cruise on board the research ship BIP XII in February 2005. The average temperature and dissolved oxygen concentration were $14.5^{\circ} \mathrm{C}$ and $1.01 \mathrm{mg} \mathrm{O}_{2} \mathrm{~L}^{-1}$, respectively. P. woolmani had not been reported at greater depth than $100 \mathrm{~m}$. This new record represents an increase of $148.1 \mathrm{~m}$ in its bathymetric distribution in the Gulf of California.
\end{abstract}

Key words: Pleuronectiformes, commercial, bathymetric distribution

\section{INTRODUCTION}

Paralichthys woolmani Jordan \& Williams in Gilbert, 1897 is an important commercial species captured in the continental shelf mainly from 45-80 $\mathrm{m}$ in depth. Its distribution has been reported from 1-100 m [Fishbase (Froese \& Pauly 2016), Integrated Taxonomic Information System (ITIS) ${ }^{1}$, Biogeographic Information \& Observation System (BIOS) ${ }^{2}$, Robertson \& Allen 2015] ranging from southern Baja California and the Gulf of California to Peru (Robertson \& Allen 2015). $P$. woolmani's oviparous form of reproduction is pelagic, a piscivore on benthic fishes occupying a trophic level of 4.5 classified as primary predator (Palacios 2011) from the San Diegan and Panamic provinces in the Eastern-Tropical Pacific (Romero et al. 2008, Acevedo et al. 2010). It forms part of shrimp by-catch fauna in the Gulf of California fisheries (Rábago et al. 2007, López et al. 2010, 201233 Herrera et al. 2015), which is why its extraction is performed by both artisanal and shrimp fleets.
\end{abstract}

\section{MATERIALS AND METHODS}

Specimens of Paralichthys woolmani were captured in the central Gulf of California on board the research ship BIP XII in an exploration cruise in February 2005, temperature; dissolved oxygen and salinity concentration were recorded with an autonomous monitoring equipment type CTD SD 204. Each throw was performed with one hour of effective trawling with a bottom trawl made with braided polyethylene with a mesh opening of $2.54 \mathrm{~cm}$ size $38 / 34 \mathrm{~m}$, mouth perimeter of $68 \mathrm{~m}$, and upper ropes of $38 \mathrm{~m}$. The net operated astern at depths from $90-540 \mathrm{~m}$, at a speed of $5.5 \mathrm{~km} \mathrm{~h}^{-1}$. Once on board the capture was emptied on deck, and $20 \mathrm{~kg}$ of the sample were taken at random for analyses in the Fisheries Laboratory at CIBNOR-Sonora Unit. For its identification, Hensley (1995) and Robertson \& Allen $(2002,2015)$ keys were used and the specimen vouchers in a collection of fish of Centro de Investigaciones Biológicas del Noroeste, S.C. in La Paz, Mexico.

Main characters used to differentiate $P$. woolmani: body height $43-53 \%$ of standard length SL; head length $26-32 \%$ of SL, the dorsal fin begins over upper eye, $70-81$ rays and lateral line scales 93-110.

The bathymetric distribution at depth: 1-91 m.

Paralichthys aestuarius: body height $43-44 \%$ of SL; head length $27 \%$ of SL; $24-31$ gill rakers; dorsal fin $72-85$ rays; anal fin 57-67 and the lateral line scales 96-119.

The bathymetric distribution at depth: 0-45 m.

\footnotetext{
${ }^{1}<$ http://www.itis.gov/>

${ }^{2}<$ https://www.wildlife.ca.gov/Data/BIOS>

${ }^{3}$ López J, J Rodríguez, A Acevedo, E Herrera \& J Rodríguez. 2012. Impacto de las actividades pesqueras en la reserva de la biosfera del Alto Golfo de California. Centro de Investigaciones Biológicas del Noroeste, S.C. Informe Final, 120 pp.
} 


\section{RESULTS AND DISCUSSION}

Ten Paralichthys woolmani individuals were captured in the coordinates shown in Table 1 . The station at greatest depth $(248.1 \mathrm{~m})$ with positive collection was located at $28.374^{\circ} \mathrm{N}$, $112.16^{\circ} \mathrm{W}$, and $44 \mathrm{~km}$ from the coast, representing an increase of $148 \mathrm{~m}$ from the previously reported bathymetric distribution. Flounders showed gonads in advanced maturity stage with sizes from $15.0-29.0 \mathrm{~cm}$ in total length, considered as adults (Benetti et al. 1995). In this location, from the shallowest to the greatest depth (2.54-300 m), sea temperature varied from 17.8 to $11.76^{\circ} \mathrm{C}$, while dissolved oxygen showed variations between 7.31-0.092 $\mathrm{mL}^{-1}$; also, salinity varied from 35.2 to 34.8 (Fig. 1). At $248 \mathrm{~m}$, the environmental conditions were: temperature $12.01^{\circ} \mathrm{C}$, salinity 34.86 , and dissolved oxygen $1.01 \mathrm{mg} \mathrm{L}^{-1}$, with greater variations in temperature of $5.8^{\circ} \mathrm{C}$ and minimum variation in salinity of 0.4 .
Table 1. Record of organisms captured by station, depth, number of organisms, size and geographical position in the exploration cruise in the central Gulf of California in February 2005 / Registro de organismos capturados por estación, profundidad, número de organismos, talla y posición geográfica durante el crucero de exploración en el centro del Golfo de California en febrero 2005

\begin{tabular}{ccccc}
\hline Station & $\begin{array}{c}\text { Depth } \\
(\mathrm{m})\end{array}$ & $\begin{array}{c}\text { No. of } \\
\text { organisms }\end{array}$ & $\begin{array}{c}\text { Total length } \\
(\mathrm{cm})\end{array}$ & $\begin{array}{c}\text { Coordinates } \\
(\text { Latitude - Longitude) }\end{array}$ \\
\hline 27 & 248.1 & 2 & $27.2-29.0$ & $28.374^{\circ} \mathrm{N}-112.16^{\circ} \mathrm{W}$ \\
23 & 109 & 2 & $20.2-26.0$ & $28.111^{\circ} \mathrm{N}-111.34^{\circ} \mathrm{W}$ \\
16 & 171 & 2 & $27.2-28.0$ & $27.453^{\circ} \mathrm{N}-110.71^{\circ} \mathrm{W}$ \\
12 & 108 & 2 & $15.2-31.0$ & $27.073^{\circ} \mathrm{N}-110.44^{\circ} \mathrm{W}$ \\
9 & 162 & 2 & $22.0-26.0$ & $26.872^{\circ} \mathrm{N}-112.23^{\circ} \mathrm{W}$ \\
\hline
\end{tabular}

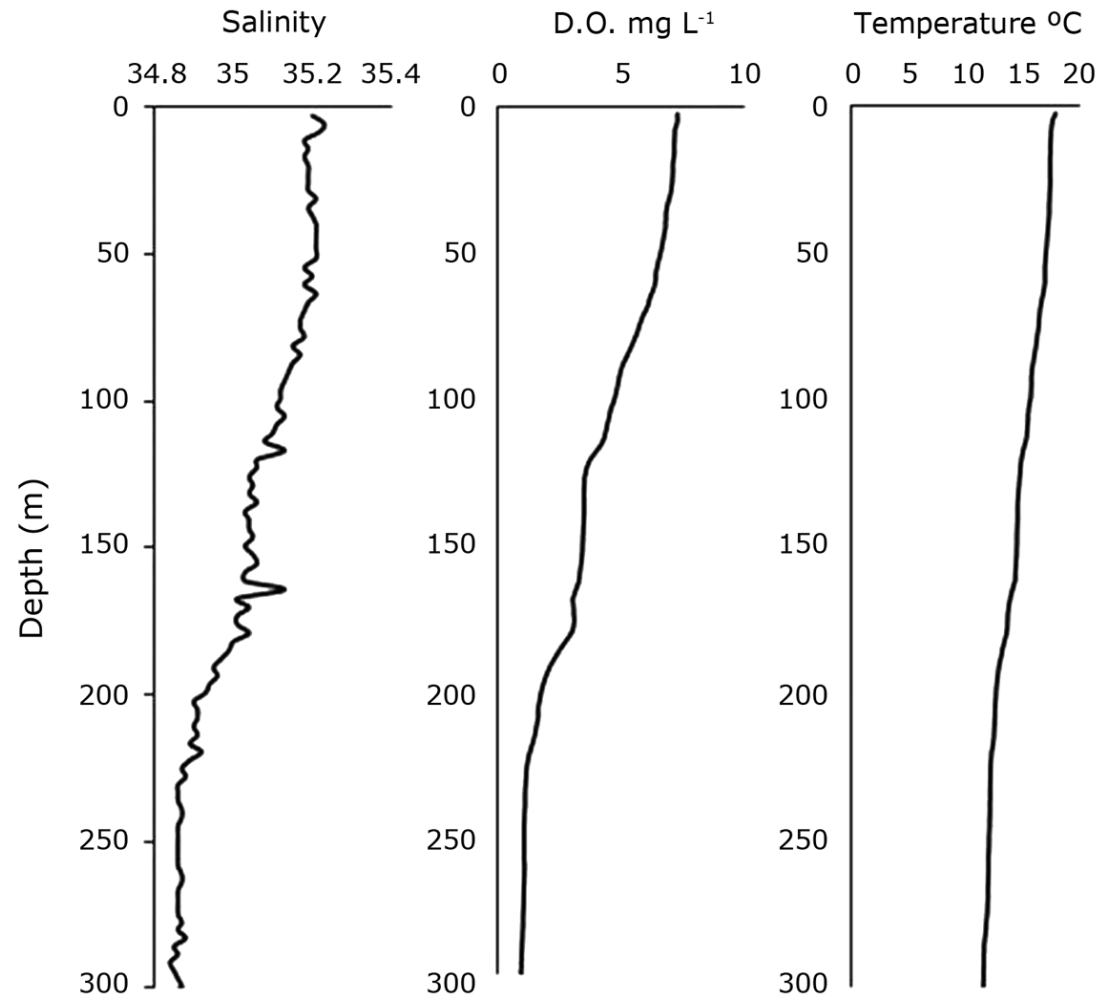

Figure 1. Vertical distribution of temperature, dissolved oxygen, and salinity in the deepest station where the Dappler flounder Paralichthys woolmani was captured in the in-depth exploration cruise in the central Gulf of California in February 2005 / Distribución vertical de la temperatura, oxígeno disuelto, y salinidad en la estación más profunda donde se capturó a la Platija moteada Paralichthys woolmani durante el crucero de exploración a profundidad en el centro del Golfo de California en febrero 2005 
Hendrickx \& Serrano (2010) found the oxygen minimum zone (OMZ) at $255 \mathrm{~m}$ depth in the central Gulf of California, that is, dissolved oxygen concentration lower than $0.5 \mathrm{mg} \mathrm{L}^{-1}$, which agrees with the data reported in our study. In the OMZ, the presence of the species is scarce, because species richness can be low in anoxic and hypoxic benthic bands $\left(0-5 \mathrm{mg} \mathrm{L}^{-1}\right)$. In this sense, some species have developed physiological adaptations and/or special behaviour to subsist in minimum oxygen conditions because OMZ represents a physiological barrier for vertical migration in the water column limiting these species to inhabit either above or below this zone. On the other hand, $P$. woolmani is a species showing medium resilience and duplicates its population in 4 years (Robertson \& Allen 2015), which could be interpreted as reproductive success due to its adaptation to survive in low dissolved oxygen environments. In general, depth species (>200 m) show life histories type K (long life, late maturity, low fecundity, and low growth), which differs from species in the continental shelf (Hendrickx \& Serrano 2010). Therefore, it is essential to know as precisely as possible its distribution and abundance to collaborate to its biological knowledge and conservation.

\section{ACKNOWLEDGMENTS}

This project was funding by SAGARPA-CONACYT 2003002-024, and EP CIBNOR project. We thank INAPESCA and CONAPESCA for the PPF DGOPA.02226.1104070937. We thank Edgar Arzola Sotelo for logistical work. The authors would like to thank D. Dorantes for English edition.

\section{LITERATURE CITED}

Acevedo A, J López, E Herrera \& J Rodríguez. 2009. Análisis de la abundancia, dominancia y diversidad de la comunidad de peces demersales de profundidad de 90 a 540 metros en el Golfo de California, México. Interciencia 34(9): 660-665.

Benetti D, A Acosta \& J Ayala. 1995. Cage and pond Aquaculture and Marine Fin fish in Ecuador. World Aquaculture Baton Rouge 26(4): 7-13.

Froese R \& D Pauly. 2015. FishBase. <www.fishbase.org, version>

Hensley D. 1995. Paralichthyidae. Lenguados. In: Fischer W, F Krupp, W Schneider, C Sommer, K Carpenter \& V Niem (eds). Guía FAO para identificación de especies para los fines de la pesca. Pacifico Centro-Oriental 3: 1349-1380. FAO, Rome.
Hendrickx M \& D Serrano. 2009. Impacto de la zona de mínimo oxígeno sobre los corredores pesqueros en el Pacífico mexicano Interciencia 35: 1-17.

Herrera E, J López \& S Vargasmachuca. 2015. Estrés en la comunidad íctica en la pesca de arrastre del camarón en el norte del Golfo de California. Revista de Biología Tropical 63(3): 741-754

Jordan D \& B Evermann. 1896-1900. The fishes of North and Middle America. Part. I (1896), II (1898), III (1898) \& IV (1900). Bulletin of the United States Natural History Museum 47: 1-3313.

López J, E Herrera, J Rodríguez \& V Hernández. 2010. Composición taxonómica de peces integrantes de la fauna de acompañamiento de la pesca industrial de camarón del Golfo de California, México. Revista de Biología Tropical 58: 925-942.

López J, A Acevedo, E Herrera, J Rodríguez \& S Palacios. 2013. Composición taxonómica y aspectos zoogeográficos de peces de profundidad (90-540m) del Golfo de California, México. Revista de Biología Tropical 60: 347-360.

Palacios S. 2011. Patrones latitudinales de composición y diversidad funcional de peces asociados a la pesca de camarón del Pacífico mexicano. Tesis de Doctorado en Ciencias Marinas, CICIMAR-IPN, La Paz, B.C.S., México, $168 \mathrm{pp}$.

Rábago C, J López, E Herrera, M Nevárez \& J Rodríguez. 2008. Population dynamics and spatial distribution of flatfish species in shrimp trawl bycatch in the Gulf of California. Hidrobiología 18: 193-202.

Rodríguez J, S Palacios, J López \& G Ponce. 2008. Composición y zoogeografía de los peces demersales de la costa occidental de Baja California Sur, México. Revista de Biología Tropical 56: 1765-1783.

Robertson DR \& GR Allen. 2002. Shorefish of the tropical eastern Pacific: An information system. Smithsonian Tropical Research Institute, Balboa. [CD ROM]

Robertson DR \& GR Allen. 2015. Especie: Paralichthys woolmani, Lenguado huarache. En: DR Robertson \& GR Allen (eds). Peces costeros del Pacífico Oriental Tropical: Sistema de Información en línea. Versión 2.0 Instituto Smithsonian de Investigaciones Tropicales, Balboa.<http:// biogeodb.stri.si.edu/sftep/es/thefishes/species/2336> 